\title{
BIBLIOMETRIC ANALYSIS OF ACADEMIC PUBLICATIONS ABOUT GREEN SUPPLY CHAIN MANAGEMENT: Limits and Possibilities
}

\author{
ANÁLISE BIBLIOMÉTRICA DE PUBLICAÇÕES ACADÊMICAS SOBRE A GESTÃO DA \\ CADEIA DE SUPRIMENTOS VERDE: Limites e Possibilidades
}

\author{
Nágela Bianca do Prado a, Gustavo Hermínio Salati Marcondes de Moraes a \\ aUniversidade Estadual de Campinas - UNICAMP \\ nagelabianca.prado@gmail.com,salati@unicamp.br
}

Submissão: 31 de agosto de 2021 Aceitação: 06 de novembro de 2021

\begin{abstract}
This study aims to present a bibliometric overview about the relationship between GSCM and environmental sustainability in academic articles indexed on Web of Science and Scopus databases, between 2000 and 2020. For this, it was used the bibliometric analysis procedure combining a quantitative and a qualitative approach, reporting the main findings through bibliometric indicators and VOSviewer software. In relation to the findings, it was possible to confirm and identify that (a) in the last twenty years the theme has gained relevance, with an increasing number of studies; (b) the main research authors on the topic are American and Chinese, with a special focus on Joseph Sarkis and Syed Khan; (c) the main countries whose universities focus their research on GCSV and sustainability are the United States and China; (d) the Journal of Cleaner Production is the journal that most indexes subjects related to the theme; (e) the manufacturing sector is the most investigated; (f) the effectiveness of implementing GCSV faces numerous barriers, which become more complex according to the region; and $(\mathrm{g})$ recent research is studying the relationship between GSCM and information technology. Finally, the originality of the study lies in providing a broad and in-depth overview about the GSCM framework, combining a mixed analysis methodology, contributing to future research on the theme.
\end{abstract}

Keywords: Green Supply Chain Management; GSCM; Bibliometric Analysis.

\section{Resumo}

Este estudo tem como objetivo apresentar um panorama bibliométrico sobre a relação entre a GCSV e sustentabilidade ambiental em artigos acadêmicos indexados nas bases de dados Web of Science e Scopus, entre 2000 e 2020. Para tanto, utilizou-se o procedimento da análise bibliométrica combinando uma abordagem quantitativa e uma abordagem qualitativa, para relatar os principais achados por meio de indicadores bibliométricos e do software VOSviewer. Em relação aos achados, foi possível confirmar e identificar que (a) nos últimos vinte anos o tema ganhou relevância, com um número crescente de estudos; (b) os principais autores das pesquisas sobre o tema são norte-americanos e chineses, com destaque para Joseph Sarkis e Syed Khan; (c) os principais países cujas universidades concentram suas pesquisas em GCSV e sustentabilidade são os Estados Unidos e a China; (d) o Journal of Cleaner Production é o periódico que mais indexa assuntos relacionados ao tema; (e) o setor manufatureiro é o mais investigado; (f) a eficácia da implementação da GCSV enfrenta inúmeras barreiras, que se tornam mais complexas conforme a região; e (g) pesquisas recentes estão estudando a relação entre GCSV e a tecnologia da informação. Por fim, a originalidade do estudo está em fornecer um panorama amplo e aprofundado sobre a GCSV por meio de uma metodologia de análise mista, contribuindo para pesquisas futuras sobre o tema.

Palavras-chave: Gestão da Cadeia de Suprimentos Verde; GCSV; Análise Bibliométrica. 


\section{INTRODUCTION}

In the last decades, sustainable themes have increased in the most diverse categories of human activities and, specifically, in business management practices, due to environmental concerns arising from production and consumption processes (GIANNETTI et al., 2020). The sustainability integration in business aims to include the so-called ecological practices, executed in such a way that future needs are not compromised in detriment of meeting the current generation needs (YU et al. 2014; HASHEMI; KARIMI; TAVANA, 2015; SANGODE; METRE, 2019). Moreover, in relation to the business environment, a more specific and measurable conceptualization of sustainability takes into account the social, ecological and economic dimensions, commonly called 'triple bottom line' (FAHIMNIA; SARKIS; DAVARZANI, 2015).

In this context, concerns about the sustainable management of supply sources in the production chain have also emerged in an attempt to ensure long-term business sustainability (MODAK et al., 2020). Conceptually, the supply chain implies a set of relationships established between materials and services suppliers that undergo production processes and activities that result in products delivered to consumers (CARBALLO-PENELA et al., 2018).

Traditionally, supply chain management has focused on delivering products to the final consumer (SHAFIQUE; ASGHAR; RAHMAN, 2017). In addition, companies consider basic criteria such as price, quality, and flexibility when defining suppliers (SHEN et al., 2013). Furthermore, looking at the way the supply chain had developed in the past, the production, and operation of the supply chain had consumed a large amount of energy and resources, producing numerous goods and pollutants denoting greater pressure for environmental protection (GONG et al., 2019). As a consequence, several spheres of society have created methodologies for quantifying environmental impacts in the supply chain, as well as identifying the implementation of improvements (CARVALHO et al., 2020).

However, the globalization advent has caused countries to conflict with each other over issues that involve energy consumption and environment protection. As a result, supply chains are under increasing pressure on natural resources and demand to reduce the environmental impact of their activities. According to Zhou, $\mathrm{Li}$, and $\mathrm{Ma}$ (2021), supply chain management is a vital theme in sustainable develop- ment, as it reflects the rationality of business practices and resource consumption patterns.

Additionally, with the growing global awareness of protecting the environment, a new concept of supply chain management has emerged and has gained special attention: Green Supply Chain Management (GSCM). This concept has been developed in several countries motivated by the need for ecologically correct disposal of solid waste, awareness of natural resources and reduction of water and air pollution, as well as by the influence of society and pro-environmental legislation (ALTAF; ALI; WEBER, 2020).

The main objective of GSCM is to reduce harmful environmental influences as much as possible, such as air and water pollution, and to improve the ability to manage the resources of waste, such as energy, materials, and products (AMIRBAGHERI et al., 2019). In addition, the GSCM aims to implement the principles of environmental awareness in all phases of supply chain management (CARVALHO et al., 2020).

Nowadays, the incentive to adopt green supply chain management practices is not mostly driven by mandatory regulations, as it was in the past. Currently, there are environmental programs that consider the implementation of such practices a win-win situation, considering the positive environmental and economic impacts (CARVALHO et al., 2020) and, with that, the adoption of GCSV allows improvements in performance (MADITATI et al., 2018; OLIVEIRA et al., 2018).

This new concept, according to Shen et al. (2013), started to gain credibility in the late 1980s with the clean technologies introduction and in parallel with programs to reduce environmental impacts in the main production process stages. More specifically, in 1990 companies began to redouble their efforts in an attempt to offer environmentally friendly products and services (SHEN et al., 2013). Thus, GSCM aims to manage the "normal" flow of the chain so as not to have significant environmental impacts (AGARWAL; GIRAUD-CARRIER; LI, 2018; PHAWITPIRIYAKLITI et al., 2020).

Several authors have carried out bibliometric research on the GSCM theme. Each identified work, however, addresses different points of view about the subject. For example, Oliveira et al. (2018) carried out a systematic literature review related to the GSCM, whose focus of analysis was based on the main contexts, areas, and research methodologies. Maditati et al. (2018), on the other hand, promoted a bibliometric review on the GSCM and, in parallel, 
provided a conceptual framework together with directions for future research in relation to the theme. In addition, the authors investigated the main drivers, practice indicators and performance measures. Amirbagheri et al. (2019) proposed a bibliometric review of GCSV from 1995 to 2017, with a strictly quantitative focus on a database - Web of Science. The same occurred with the research by Carvalho et al. (2020), which investigated the main associations between innovation and GSCM, with a strictly quantitative focus only on Web of Science databases.

Despite the studies mentioned present valuable information on the state-of-the-art about the GSCM thematic, there is still a gap for the elaboration of a bibliometric study to allow a better understanding of the theme. In this sense, this study proposes a bibliometric revision in the period from 2000 to 2020, on the relationship of GSCM and environmental sustainability in academic articles indexed in two databases, reporting the main findings through bibliometric indicators and VOSviewer software.

The contribution of this study is to summarize the GCSV theme from different perspectives, combining quantitative and qualitative analysis of the state-of-the-art, in order to provide references to future research, so that each reader can understand the data according to their interests and priorities on the topic. In addition, the main innovation of this study is to associate quantitative indicators with a complementary qualitative analysis based on articles indexed in two databases: Web of Science and Scopus.

This article is structured as follows: after this introduction, the methodological procedures are presented in section two; the bibliometric and exploratory results exposition, in section three, gather with the findings discussion based on the theoretical framework; and final considerations, in section four, followed by references.

\section{METHODOLOGY}

This study used the bibliometric analysis procedure to achieve its research objective. According to Van Eck, and Waltman (2009), this procedure is characterized by its primarily quantitative character, which even sets it apart from bibliographic research. Bibliometric studies, in general, are developed from large secondary databases. This study aimed to analyze academic publications on GSCM to understand the theme evolution in the last century and its relationship with environmental sustainability. Thus, bibliometric analysis can show how this theme is being addressed in journals of relevance to the administration area. To this end, the timeline included documents published between 2000 and 2020 .

It should also be noted that, for the analysis, only publications of scientific articles in journals were considered. To find the material, the following terms were used in the search within articles' title, abstract, and keywords: "supply chain management", "green", "green supply chain management", "GSCM" and "environmental sustainability". The investigations were carried out in two databases: Scopus and Web of Science.

The choice for using two databases was due to the fact that they are internationally recognized and widely used by different researchers of different levels and areas, mainly in the administration area (MODAK et al., 2020). Amirbagheri et al., 2019 justify the use of both, also in a bibliometric research, as they consider that they are frequently used and accepted in bibliographic analyzes. In addition, they present a large amount of details of the articles, such as year of publication, authors, authors' affiliation, categories etc. (MADITATI et al., 2018; OLIVEIRA et al., 2018; AMIRBAGHERI et al., 2019; ZHOU; LI; MA, 2021).

Likewise, the terms chosen, which were briefly based on 'green supply chain management and environmental sustainability' were purposely broad in order to verify which research associations are made to them. Bibliometric research that seeks to verify the limits of a theme usually uses comprehensive terms (MADITATI et al., 2018).

It was opted only for articles written in English. This choice is based on the fact that most international journals only publish works in English. Another fact is that English is an internationally known and globally spoken language.

Regarding the research procedures, the first step was to access the databases and to parameterize them with the search syntax, so that the file metadata could be downloaded. The next step was to gather metadata from both bases in Mendeley and eliminate duplicate articles. With the gross total of works recovered, quantitative (or descriptive) analysis was performed. Then, the papers had their titles and abstracts read in order to verify which ones were more aligned with the research objectives. With this refinement procedure, a final amount was reached for the qualitative (or exploratory) analysis to be carried out. This description is illustrated in Figure 1.

The bibliometric procedure has several indica- 
tors that assess the performance of scientific production. Some indicators were used in the present study, which will be discussed in the next section. For the articles' selection, there was a refinement process, illustrated in Figure 1. At the end of the refinement process, a total of 53 bibliographic records were selected for exploratory analysis (Chart 1).

Chart 1 summarizes the stages of document refinement: 125 articles from Scopus and 176 from Web of Science were retrieved, adding up to a total of 301 papers. After eliminating duplicates, 227 articles comprised the sample used for descriptive analyzes, which were based on the chronological distribution of publications, authorship, countries, journals, and keywords. For qualitative analysis, at first the titles that were closest to the objective of the study were read. The selected titles also had their abstracts read and, from them, a new sample made up the exploratory analysis, adding up to a total of 53 articles. below.

The discussion of the findings will be presented

\section{RESULTS DISCUSSION}

\subsection{Descriptive bibliometric analysis}

This topic is intended for the so-called 'research profiling', which promotes an analysis of the literature in order to answer the questions: what is the chronological evolution of publications? Who are the main authors and their institutions? What are the main countries dedicated to researching the theme? What are the main journals that index the subject? What are the main keywords representing GCSV and environmental sustainability?

Therefore, analyzes were carried out with the "gross" results supported by the search for keywords in the two databases mentioned, with an amount of 168227 studies, carried by Microsoft Excel and VOSviewer version 1.6.13.

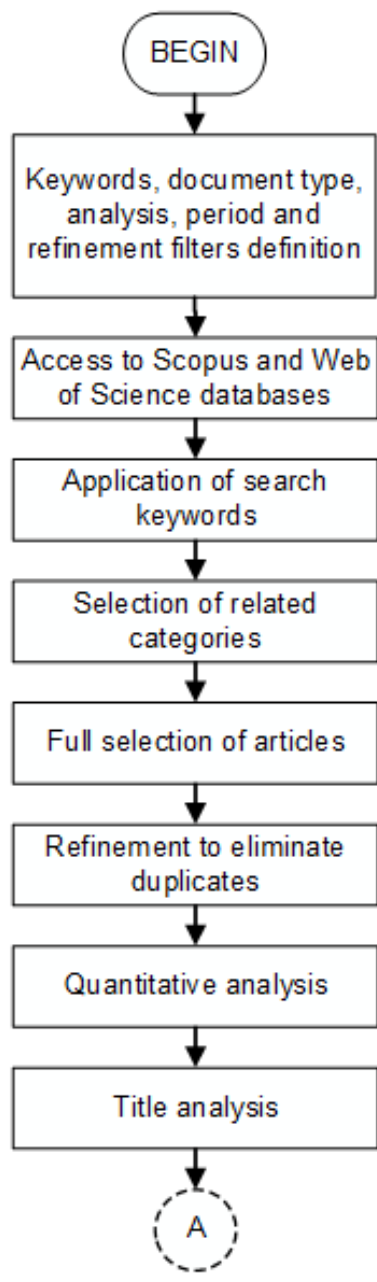

Figure 1 - Articles refinement stages summary

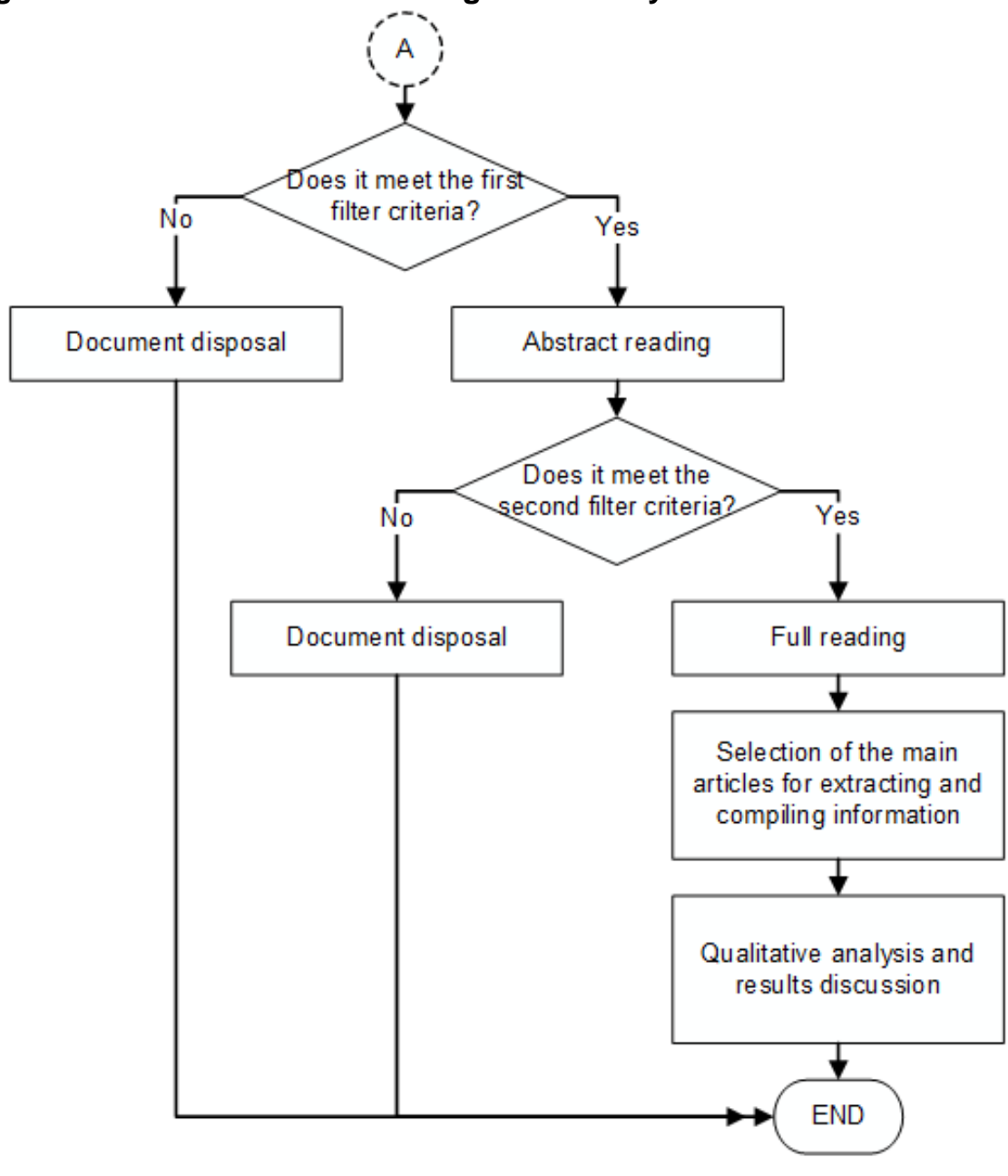

Source: Own authorship. 


\section{Chart 1 - Refinement stages}

\begin{tabular}{|c|c|c|c|c|c|}
\hline Database & Period & Type & Keywrds & Categories & Results \\
\hline Scopus & & & $\begin{array}{l}\text { (“Supply chain } \\
\text { management" } \\
\text { AND ("green" OR }\end{array}$ & $\begin{array}{l}\text { Business, management and accounting } \\
\text { OR engineering OR environmental sci- } \\
\text { ence OR decision science OR social sci- } \\
\text { ence }\end{array}$ & 125 \\
\hline $\begin{array}{c}\text { Web of Sci- } \\
\text { ence }\end{array}$ & $2000-2020$ & Article & $\begin{array}{c}\text { “green supply } \\
\text { chain manage- } \\
\text { ment" OR } \\
\text { "GSCM") AND } \\
\text { (“environmental } \\
\text { sustainability")) }\end{array}$ & $\begin{array}{l}\text { Management OR environmental sci- } \\
\text { ences OR operations research manage- } \\
\text { ment science OR engineering manufac- } \\
\text { turing OR engineering industrial OR } \\
\text { green sustainable science technology } \\
\text { OR engineering environmental OR busi- } \\
\text { ness OR environmental studies }\end{array}$ & 176 \\
\hline \multicolumn{5}{|r|}{ Grand total } & 301 \\
\hline \multicolumn{5}{|c|}{ Total after checking duplicates / reading the title / bibliometric analysis } & 227 \\
\hline \multicolumn{5}{|r|}{ Selected for reading the abstract } & 134 \\
\hline \multicolumn{5}{|r|}{ Selected for full reading } & 68 \\
\hline \multicolumn{5}{|c|}{ Selected for information extraction / exploratory analysis } & 53 \\
\hline
\end{tabular}

Source: Own authorship.

\subsubsection{Chronological distribution of publica- tions on GSCM}

Based on Figure 2, it is possible to observe that scientific publications on GSCM, resulting from a search involving several refinements, had an exponential growth since 2007, the year in which the publications that met the criteria for research began. Especially in 2012, publications increased and, later, doubled in 2015. In 2016 studies had a slight decline, which was recovered in 2017, suffering a big increase in 2018 until 2020.

In this way, Cankaya, and Senzen (2019) present a possible justification for the increase in publications in recent years, arguing that the fact of the natural resources depletion, environmental pollution, global warming and the several animal species extinction is leading governments, companies and individuals to adopt actions to reverse current unsustainable world scenario. According to Amirbagheri et al. (2019) parallel with the application of environmental management programs and green practices in supply chain management in the corporate environment, there has been a significant increase in academic studies on GCSV, mainly in the administration area due to the pressures that consumers themselves impose on companies to conduct their processes in a way that does not negatively impact the environment.

\subsubsection{Authorship}

From Chart 2, it is possible to analyze the ten authors with the largest publications number resulting from the search performed. It is also possible to view the institutions in which they are affiliated and the corresponding countries.

The h-index, created in 2005 by Jorge Hirsch, aims to quantify the researchers' productive impact based on the most cited articles. In the case of Joseph Sarkirs, his h-index of 91 means that the author has 91 articles that have been cited at least 91 times. Therefore, the $\mathrm{h}$-index is a metric that fluctuates according to the citations of the last article published by the author, in addition to being influenced by the publication area.

In this study, the top ten authors have a significant h-index. The main universities' countries are United States, China and United Kingdom and, consequently, they are the most influential in the theme Taking Joseph Sarkis as an example again, it is observed that the author is affiliated to a North American institution, corroborating the results, presented below, which show United States as the publications' leader on the theme. Other bibliometric analyses also found Sarkis as the main author (OLIVEIRA et al., 2018; AMIRBAGHERI et al., 2019; ZHOU; LI; MA, 2021).

To support the analysis of the main authors, the citations network was created (Figure 3 ). It is a graphic representation of the most cited authors. The network view is represented by labels and circles. Their size is characterized by the weight of the item, that is, by its occurrence frequency. The circles also have colors that are determined by the cluster to which the item belongs. The authors are divided into 
five clusters: the red, for example, groups six authors. Green and blue groups four authors. In general, the map demonstrates the interconnection of citations performed, which, in the present study, brings a total of 19 authors. In short, Figure 3 shows the concentration of citations mainly in Joseph Sarkis, whose h-index is significant and shows that the researcher focuses on searching for the theme.

\section{Figure 2 - Chronological distribution of publications on GSCM (in years)}

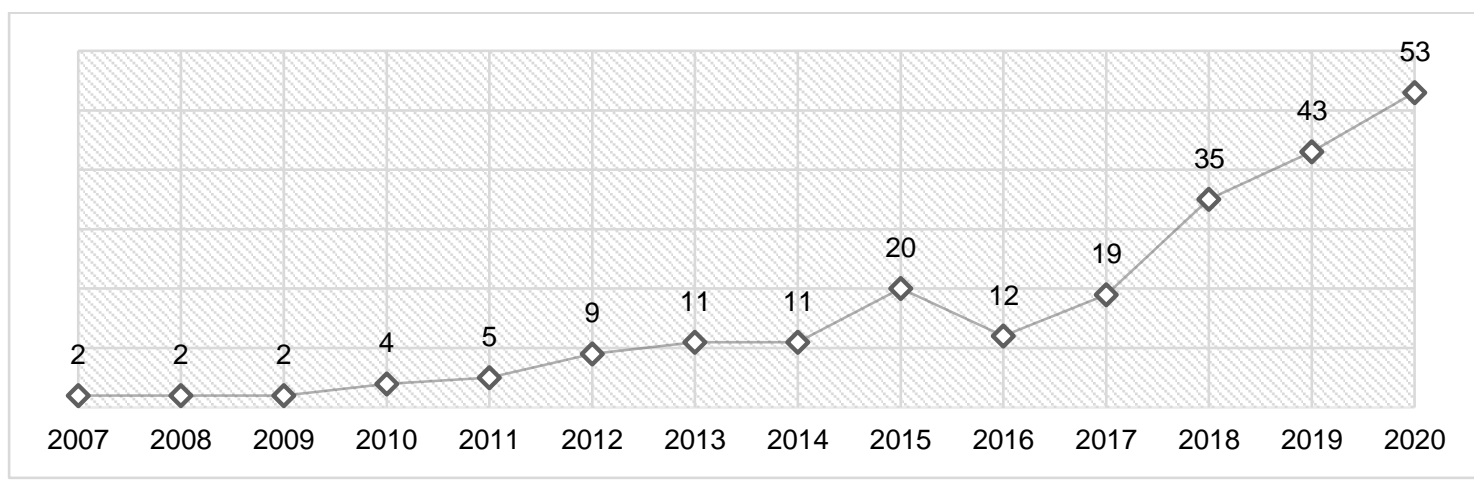

Source: Own authorship.

\subsubsection{Countries}

The analysis of countries was based on the institutions' location in which the authors are affiliated. Figure 4 illustrates the number of universities belonging to the authors who research on the theme proposed. Thus, The United States and China are the countries that lead research on the GSCM.

In relation to the USA, a possible justification for this result may be the fact that the country has the main universities in the world, where the number of researchers interested in the theme is consequently higher. Another explanation is that the country has an interest in sustainable practices to mitigate the emission of pollutants, since The United States is one of the most industrialized countries in the world. The same justification applies to China.

Sahu et al. (2018) attribute the GSCM practices implementation in emerging countries on Asian continent due to the rapid industrial modernization that these countries went through, which created substantial environmental problems that need to be reversed. However, and in general, all continents are involved with environmentally friendly concepts, as argued Mathiyazhagan et al. (2015). In the same way, Zhou, Li, and Ma (2021) propose that Asian countries, specially Chine, are rapidly improving their ratings and publication numbers for effective reasons that combine the triple bottom line of sustainability.

Taking Asian countries as the study object, a search conducted by Mani, Jabbour and Mani (2020) investigated the relationship between social sustainability and supply chain performance in 327 companies in the manufacturing sector, using structural equation modeling. The authors concluded that there is a positive relationship between sustainable practices and supply chain performance according to the size of the company and the willingness to invest in sustainable suppliers.

In this way, still according to Mani, Jabbour, and Mani (2020), emerging countries, as in the case of the vast majority of Asian countries, have a large resident population, a fact that also implies a large percentage of world exports. Thus, these countries have considerable development in terms of sustainability in the supply chain.

According to Jayarathna, and Wickramasinghe (2019), the effectiveness of adopting green practices in supply chain management differs between developed and developing countries. In the USA, for example, there is a greater level of environmental awareness that drives the voluntary adoption of GCSV. In contrast, in China, regulatory pressure requires such adoption and causes practices to be adopted to minimally comply with legislation.

To assist the geographical layout of the main countries, Figure 5 was created. From it, it is possible to understand that several European countries express the research interest on the theme, despite the number of publications not being high. The opposite is true in Africa, Asia, and South America. 
Chart 2 - Top 10 most productive authors on GSCM theme

\begin{tabular}{|l|l|l|l|l|l|}
\hline Author & $\begin{array}{l}\text { Number of } \\
\text { publications }\end{array}$ & \% from 227 & Institution & Country & H-index \\
\hline Joseph Sarkis & 8 & $3,52 \%$ & $\begin{array}{l}\text { Worcester Polytech- } \\
\text { nic Institute }\end{array}$ & United States & 91 \\
\hline $\begin{array}{l}\text { Syed Abdul } \\
\text { Rehman Khan }\end{array}$ & 7 & $3,08 \%$ & Tsinghua University & China & 24 \\
\hline Heris Golpira & 5 & $2,20 \%$ & $\begin{array}{l}\text { Islamic Azad Univer- } \\
\text { sity }\end{array}$ & Iran & 16 \\
\hline Yu Zhang & 4 & $1,76 \%$ & $\begin{array}{l}\text { Southern University } \\
\text { of Science and Tech- } \\
\text { nology }\end{array}$ & China & 28 \\
\hline Qingyun Zhu & 4 & $1,76 \%$ & $\begin{array}{l}\text { University of Ala- } \\
\text { bama in Huntsville }\end{array}$ & United States & 10 \\
\hline Anil Kumar & 3 & $1,32 \%$ & $\begin{array}{l}\text { Weizmann Institute } \\
\text { of Science }\end{array}$ & Israel & 5 \\
\hline Arshian Sharif & 3 & $1,32 \%$ & $\begin{array}{l}\text { Universiti Utara Ma- } \\
\text { laysia }\end{array}$ & Malaysia & 26 \\
\hline Lei Xu & 3 & $1,32 \%$ & $\begin{array}{l}\text { Shanghai Jiao Tong } \\
\text { University. }\end{array}$ & China & 24 \\
\hline $\begin{array}{l}\text { Andrea Geno- } \\
\text { vese }\end{array}$ & 3 & $1,32 \%$ & $\begin{array}{l}\text { University of Sheffi- } \\
\text { eld }\end{array}$ & United Kingdom & 23 \\
\hline Vikas Kumar & 3 & $1,32 \%$ & $\begin{array}{l}\text { University of the } \\
\text { West of England }\end{array}$ & United Kingdom & 33 \\
\hline
\end{tabular}

Source: Own authorship.

Figure 3 - Network citations between authors

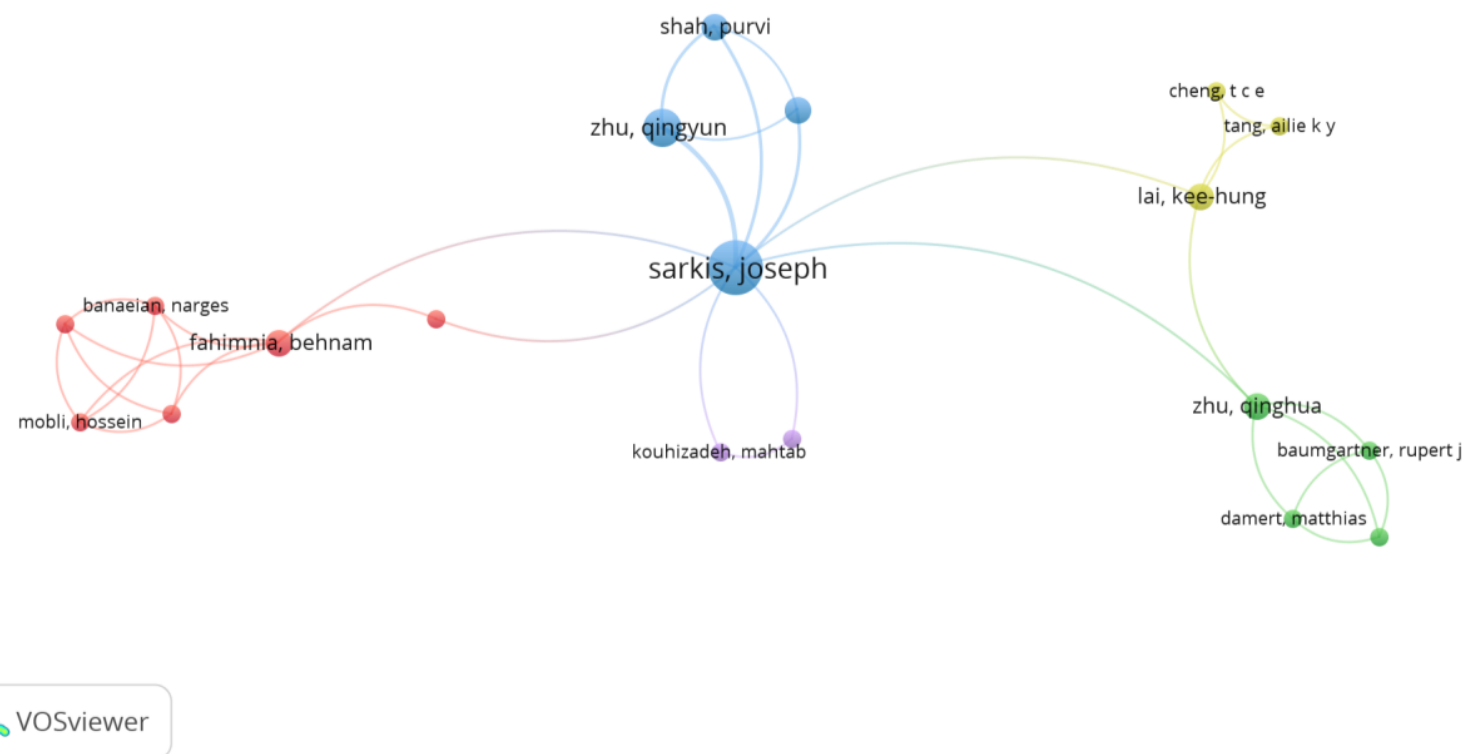

Source: Prepared by the authors using VOSviewer. 


\subsubsection{Journals}

The analysis of journals considered the number of publications on the theme by journals. For the top ten, an analysis with a greater level of detail was performed in Chart 3. Journal of Cleaner Production is the main one being an international and interdisciplinary journal, edited by Elsevier, which addresses issues about cleaner production and has one of the biggest impact factors, justifying a large publications' concentration due to the high scientific quality and prestige academic (GIANNETTI et al., 2020). This result is in accordance with Meditati et al. (2018), Amirbagheri et al. (2019), Oliveira et al. (2018), and Zhou, Li, and Ma (2021).

The impact factor is a metric that evaluates scientific journals worldwide with the aim of counting citations received by them. This indicator is calculated by dividing the sum of citations for a given period by the number sum of publications for that same period. Therefore, the journal impact factor depends on its style and the quality of its publications.

\section{Figure 4 - Countries}

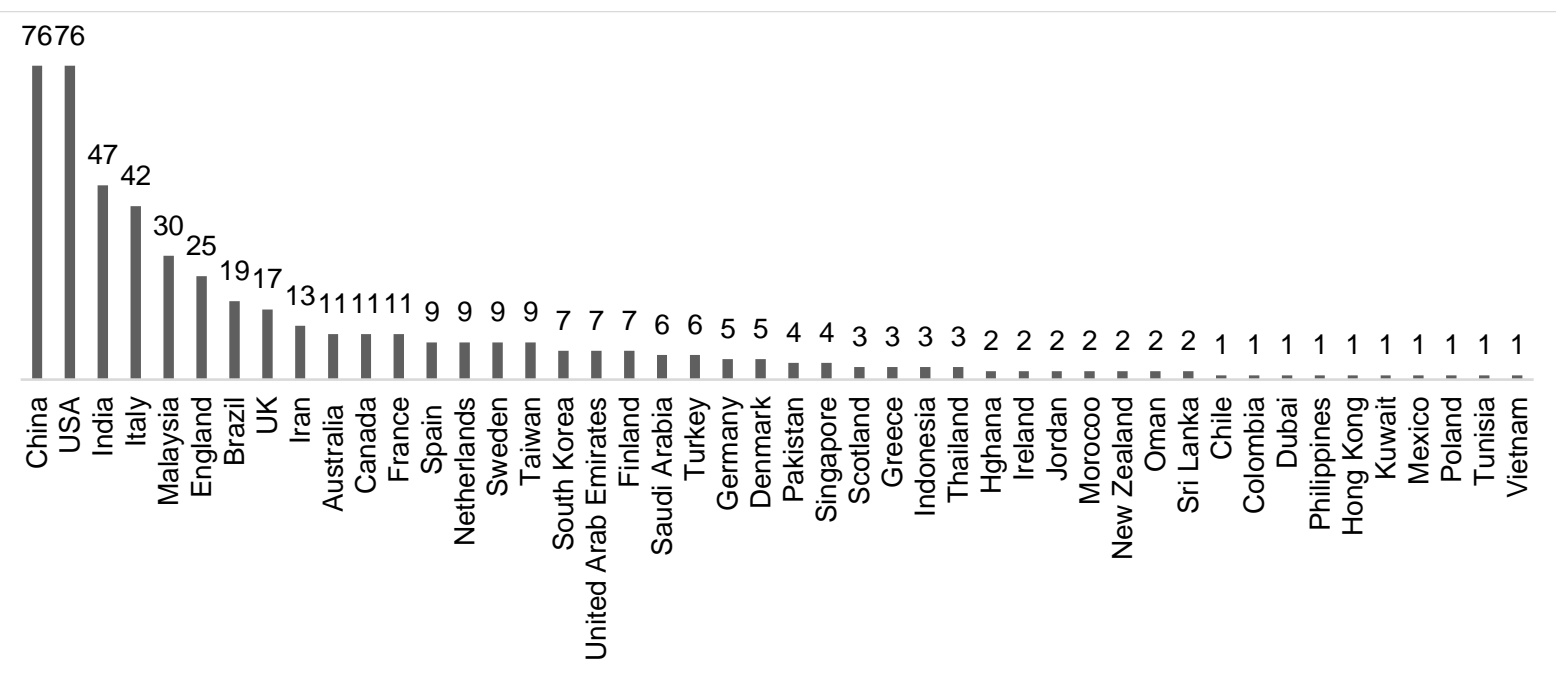

Source: Own authorship.

Figure 5 - Heat map

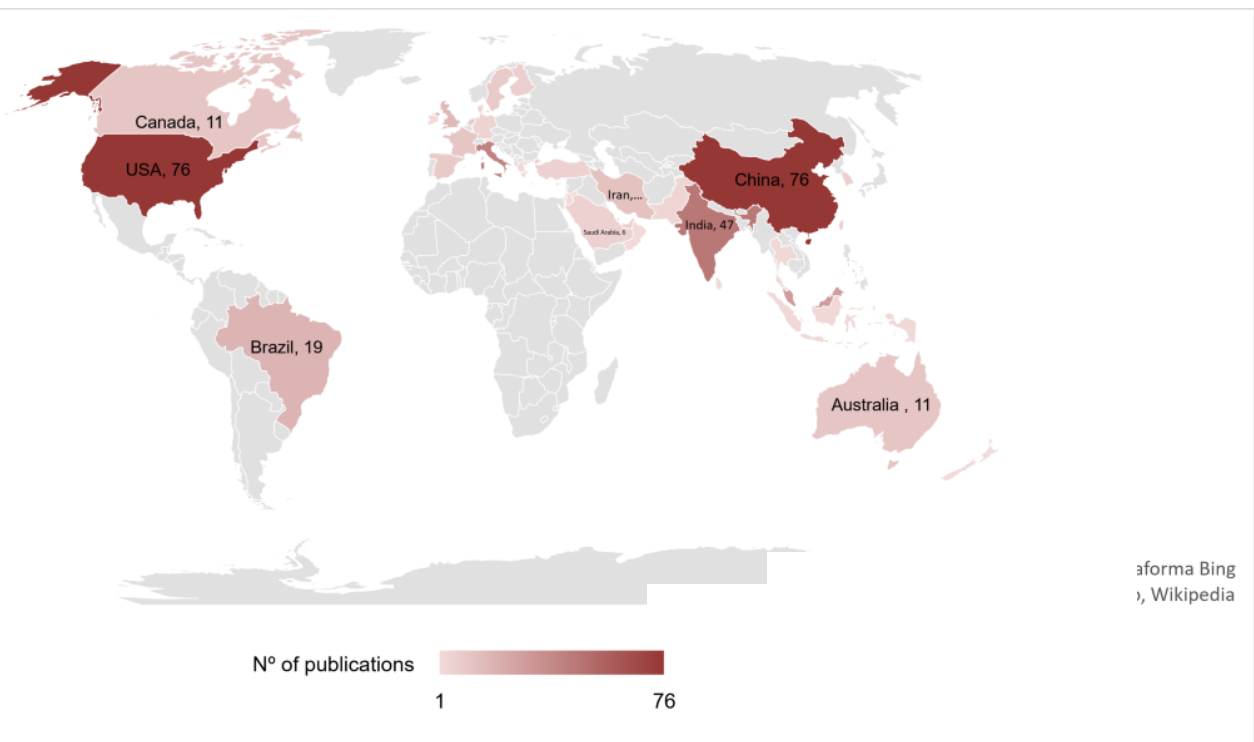

Source: Prepared by the authors using Microsoft Excel. 
Chart 3 - Top 10 mainly journals on GSCM

\begin{tabular}{|l|l|l|l|l|}
\hline \multirow{2}{*}{ Journal } & \multirow{2}{*}{ Count } & \multirow{2}{*}{ \% from 227 } & \multicolumn{2}{|c|}{ Impact factor } \\
\cline { 4 - 5 } & & & $\mathbf{2 0 1 9}$ & $\mathbf{5}$ years \\
\hline Journal of Cleaner Production & 32 & $14,10 \%$ & 7.246 & 7.491 \\
\hline International Journal of Production Economics & 15 & $6,61 \%$ & 5.134 & 6.205 \\
\hline Sustainability & 15 & $6,61 \%$ & 2.576 & 2.798 \\
\hline Resources, Conservations and Recycling & 12 & $5,29 \%$ & 8.086 & 7.589 \\
\hline International Journal of Production Research & 7 & $3,08 \%$ & 4,577 & 4,145 \\
\hline $\begin{array}{l}\text { International Journal of Logistics Research and Applica- } \\
\text { tions }\end{array}$ & 6 & $2,64 \%$ & 2,152 & 2,497 \\
\hline Journal of Manufacturing Technology Management & 6 & $2,64 \%$ & 3,385 & - \\
\hline Production Planning and Control & 6 & $2,64 \%$ & 3,605 & 3,930 \\
\hline Supply Chain Management - An International Journal & 6 & $2,64 \%$ & 4,725 & 7,207 \\
\hline Benchmarking - An International Journal & 6 & $2,64 \%$ & 3,600 & - \\
\hline
\end{tabular}

Source: Own authorship.

\subsubsection{Keywords}

The analysis of the most frequent keywords was carried out with the objective of graphically illustrating the vocabulary frequency found in the GSCM theme, which made up the articles' refinement. Chart 4 shows that the most frequent keywords. Figure 6 shows a keyword occurrence network.

VOSviewer grouped the terms shown in Figure 6 into 27 clusters, in which five have significant size. The red cluster gathered 35 terms; the green, 31; the blue 29; the yellow, 28 and the purple met 36 terms. The larger circles represent the keywords with the most repetition.

To this analysis, a diagram called "word cloud" was also constructed (Figure 7). The word cloud, in turn, illustrates the occurrence frequency of keywords and the word size that refers to the occurrence. In the present study, the diagram creation was based on keywords used at least twice.

\section{Chart 4 - Top 10 most occured keywords on GSCM theme}

\begin{tabular}{|l|c|}
\hline Keyword & Occurrence \\
\hline Supply chain management & 31 \\
\hline Sustainability & 26 \\
\hline Environmental sustainability & 25 \\
\hline Green supply chain management & 20 \\
\hline Sustainable development & 17 \\
\hline Environmental management & 12 \\
\hline Green supply chain & 9 \\
\hline Logistics & 8 \\
\hline Green & 8 \\
\hline Environmental impact & 6 \\
\hline Source: Own authorship.
\end{tabular}

\subsection{Exploratory analysis}

This section is dedicated to the qualitative analysis ofGSCM, in which it was sought to identify the state-of-the-art and the limits and possibilities of the theme. For that, the content was extracted from 53 articles, as shown in Appendix A, based on the following criteria: a) be indexed in at least one of the two selected databases; b) have been published between 2000 and 2020; c) be written in English; d) have been published in a journal; e) present in the 
title, or keywords, one of the following terms: ""green supply chain management" or "GSCM" or "environmental sustainability", and f) meet one of the categories described in Chart 1.

\subsubsection{State-of-the-art}

From Appendix $A$ it is possible to identify the title of the studies selected for content analysis, the basis they are indexed, their citations number and the authors. In general, between 2007 and 2015, articles have a large citation number. Considering 53 studies, 38 are indexed on both platforms: Scopus and Web of Science. The summarized content of these works is illustrated in Figure 8, which identifies the continent in which the work is carried out, the sector studied, the main reason why GSCM practices are implemented and, consequently, the relationship between supply chain management and sustainability, beyond the study year.

In accordance with a descriptive analysis carried out by country, a large part of the research used Asian locations as study objects. From 53 articles chosen for information extraction, 23 carried out studies in Asia, specifically in China (3), India (2), Thailand (2), South Korea (1), India (10), Pakistan
(1), Turkey (1), Iran (1), Sri Lanka (1) and Malaysia (1). Second, European countries are investigated in a total of eight studies: Spain (1), the United Kingdom (3), Sweden and Germany (3) and Finland (1). In the American continent, four studies were detected in United States and one in Brazil. One study was conducted in Oceania, specifically in Australia. Another 16 surveys were carried out worldwide using reports such as "The Global Competitiveness Report", databases such as the "Dow Jones Faction" and systematic reviews that consider multinationaldata.

As illustrated in Figure 8, the Asian continent is the one with the most studies relating GCSM and environmental sustainability in the most diverse sectors of the economy, including the chemical industry, such as Shah (2020), and the pharmaceutical industry, such as Phawitpiriyakliti et al. (2020).

In general, a large amount of the articles studied the manufacturing industry, specifically the automotive (JAYARATHNA; WICKRAMASINGHE, 2019). According to Altaf, Ali, and Weber (2020), the adoption of GCSV practices in this sector are developed specifically to improve the company's environmental performance.

\section{Figure 6 - Keywords network}

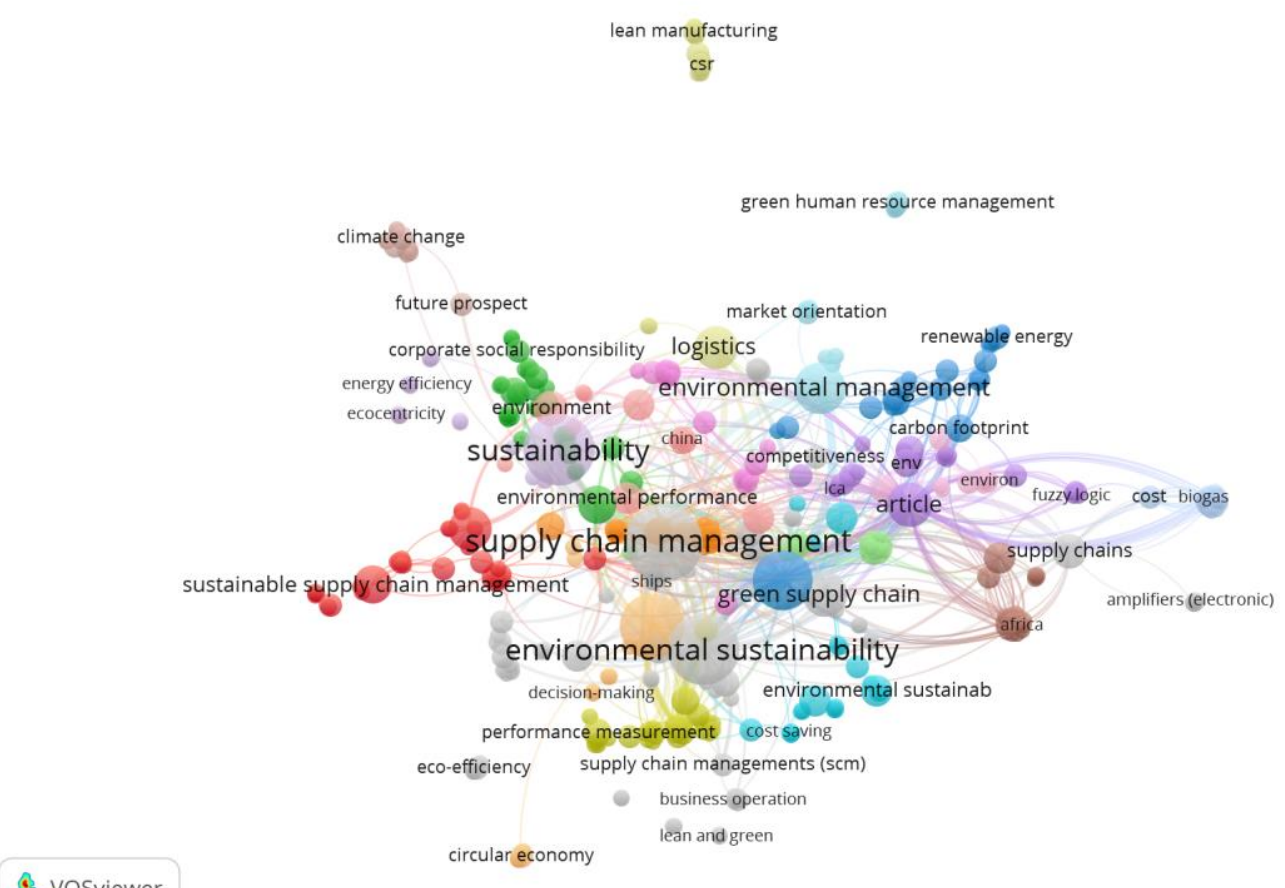

Source: Prepared by the authors using VOSviewer. 


\section{Figure 7 - Keywords cloud}

\section{\& Vosviewer}

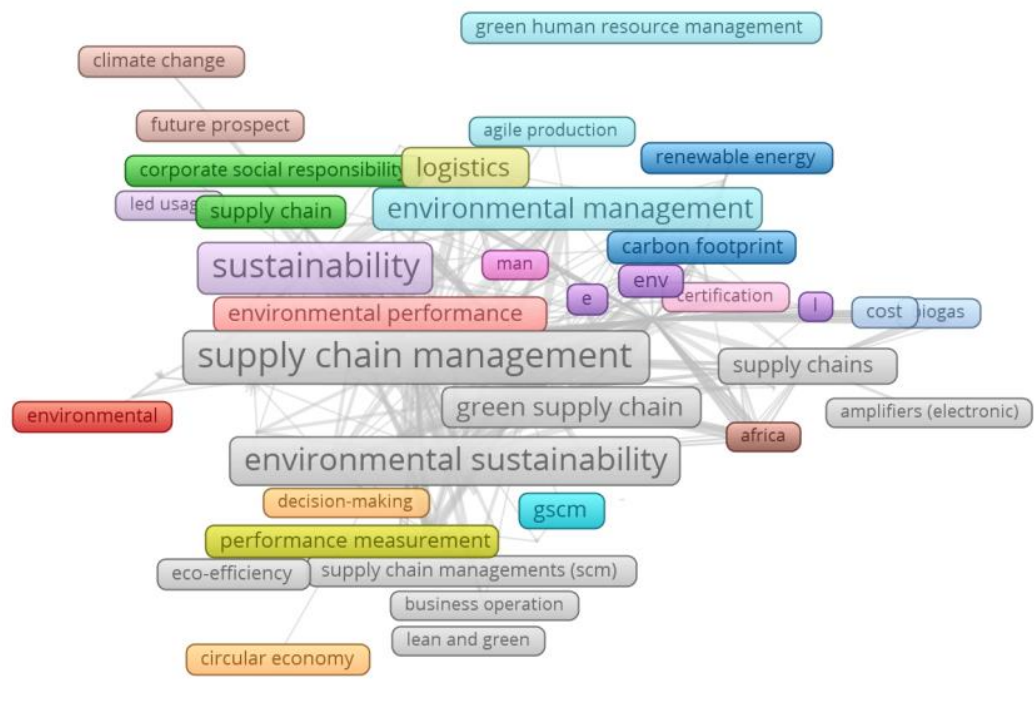

Source: Prepared by the authors using VOSviewer.

Figure 8 - Content evolution in the literature

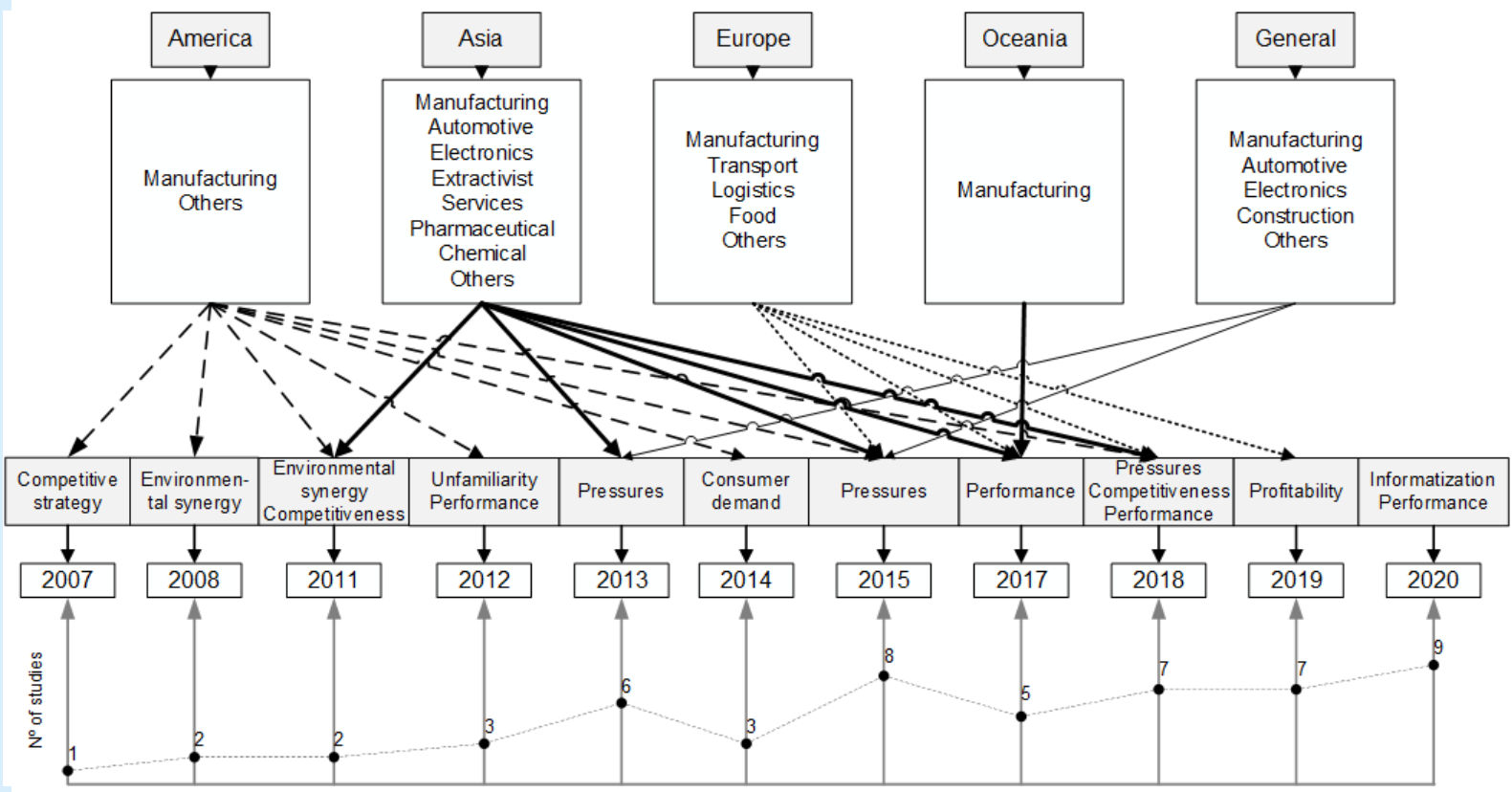

Source: Own authorship.

Logistics sector is also widely studied within GSCM "umbrella", mainly because supply chains include various activities that can damage the natural environment (ALTAF; ALI; WEBER, 2020; JAZAIRY,
2020; SARKIS; KOUHIZADEH; ZHU, 2020). According to Khan et al. (2019) logistics has an integrating function in the global supply chain and, therefore, the adoption of ecological practices implies obtaining 
economic, social and environmental advantages. In this sense, green practices that include ecological product design, cooperation with customers, green purchasing of raw materials and components, green transport and distribution, have a significant positive relationship with environmental performance (KHAN et al., 2019).

Sarkis, Kouhizadeh, and Zhu (2020) bring the 'digitalization' perspective on the theme of GCSV. More specifically, the authors investigate, from the literature, how information technologies (IT) relate to green supply chain management. As a result, the authors identified that the adoption of green information systems, including an infrastructure designed to improve the flow and management of information from the perspective of environmental sustainability, can support supply chain management activities, offering potential and advantages. The benefits include improved information traceability and management, improved communication and cooperation across the supply chain, as well as improved reliability and trust. However, it requires high investments (SARKIS; KOUHIZADEH; ZHU, 2020).

Although this study has a time frame of twenty years of coverage, the first studies adequate to the search terms appear from 2007. Therefore, as explained in Figure 8, the study's content does not yet have a chronological connection that characterizes the theme's evolution over the years. In addition, the vast majority of these articles are submitted in the "Environmental Science" and "Environmental Engineering" category.

\subsubsection{Limits and possibilities}

In order to analyze the limits and possibilities regarding the theme addressed, Figure 9 was adapted from a systematic theoretical review prepared by Tseng et al. (2019) about GSCM, aiming to link the most discussed subjects in the selected articles, which bring together the antecedents to the sustainable practices adoption, the result of this implementation, both internally and externally, and the barriers that prevent the sustainability in business dissemination.

However, prior to the effective GSCM implementation, numerous barriers arise for different reasons. Among the internal, Fahimnia, Sarkis, and Davarzani (2015), point out the confusion arising from terms classified as synonyms - such as "purchasing" and "procurement" (involves strategic purchasing activities), especially when in English language; "logistics" and "reverse logistics"; and the lack of definition of upstream logistics providers (flow towards the supplier) and downstream (flow towards the consumer) - which, if confused with traditional management, will be a shortcut to green management.

Figure 9 - GSCM structure

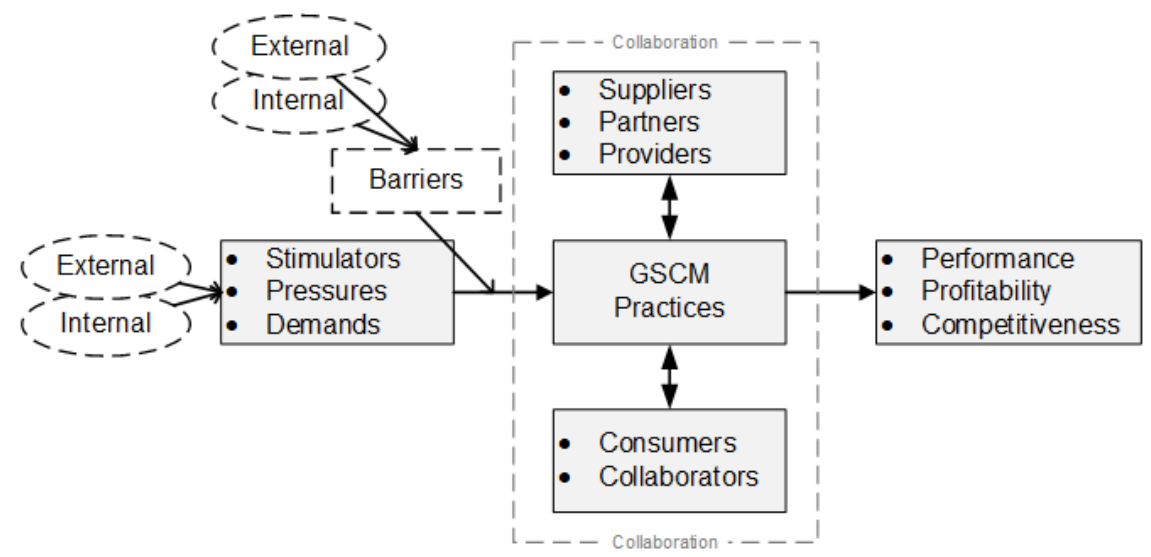

Source: Adapted from Tseng et al. (2021).

Traditional GCS, used to focus its efforts on selecting suppliers with the best prices, quality, reliability and delivery time, featuring high performance. However, with the growing global environmental awareness, managers are approaching the suppliers' selection in light of environmental aspects as an important strategy (SHEN et al., 2013; HASHEMI; KARIMI; TAVANA, 2015), expecting from them not 
only alignment of regulatory environmental compliance, but an environmentally consistent conduct (ALTAF; ALI; WEBER, 2020).

Shen et al. (2009) suggest that there is a facilitation in the GSCM adoption when there is control and prevention at the source of input and services for the company. In this way, the implementation of "green management" practices is directly related to the correct choice of suppliers, since they enter into long-term contracts with users and develop various functions and services close to their customers (TSENG; CHIU, 2013; JAZAIRY, 2020). In this context, Hashemi, Karimi, and Tavana (2015) and Govindan et al. (2020) suggest, in order to maintain competitive advantage in the global market, the adoption of critical criteria for the green suppliers' selection should be practiced throughout the various product development cycle stages.

The GSCM practices adoption is mainly a demand external to the organization, which comes mainly from consumers, competitors, and media (SHAFIQUE; ASGHAR; RAHMAN, 2017; AGARWAL; GIRAUD-CARRIER; LI, 2018). The consumers, driven by increased environmental awareness (GONG et al., 2019), are more aware about the relationship between economics and the environment and, consequently, have required companies to take a pro-environmental stance in order to minimize impacts to the environment (SHEN et al., 2013). According to Arwal, Giraud-Carrier, and Li (2018), the customer has significant pressure to adopt GSCM practices at various supply chain stages.

Regarding competitors and media, as a result of global competitiveness, companies strive to optimize their resources, improving their products and services, in order to satisfy their customers and conquer consumer loyalty (SANGODE; METRE, 2019). Therefore, by responding to their customers' requirements, companies are able to gain a competitive advantage (SHAFIQUE; ASGHAR; RAHMAN, 2017), besides getting a green reputation (MATHIYAZHAGAN et al., 2015).

The pressures, in turn, summarize government regulatory issues which vary according to the sector in which the organization operates (SHAFIQUE; ASGHAR; RAHMAN, 2017; AGARWAL; GIRAUDCARRIER; LI, 2018). In addition to external factors, internal momentum, as advocated by Agarwal, Giraud-Carrier, and $\mathrm{Li}$ (2018), characterized by the intrinsic motivation to transmit the environmental image expressed in the mission statements, values, strategies and policies, reinforce the company's incentives to adopt GSCM practices.

Specifically in the West, one of the barriers to implementing GCSV is the absence of logistical, commercial and transport infrastructure, in addition to the natural disasters that the continent added to the terrorist attacks that hamper the economic and environmental development of countries (KHAN et al., 2019). In the same sense, Altaf, Ali, and Weber (2020) argue that the practices of GCSV depend on regional, national names and, even, on the knowledge, understanding, and availability of resources.

Moreover, still in relation to internal barriers, the GSCM adoption requires a high initial investment cost, which makes the company unsure about the capital investment (SANGODE; METRE, 2019). Furthermore, environmental practices are not an independent department process, as it involves all sectors, from the input purchase to the after-sales service (MATHIYAZHAGAN et al., 2015). For Jayarathna, and Wickramasinghe (2019) there is a complexity arising from the interorganizational nature of adopting practical approaches in the supply chain, due to the diversity of systems, including interested parties with conflicting interests. Thus, the GSCM adoption requires a change in organizational culture and the consequent personal employees' awareness.

External barriers surround the government support absence and fiscal incentives for companies with ecological production initiatives; lack of training programs for employees when dealing with the new management; competition and market instability, mainly in non-developed and developing countries, regarding investment in green practices; and the difficulty of finding green suppliers for all the chain stages (TSENG et al., 2019).

Silvestre's et al. (2020) suggest that these barriers be broken with the 'learning processes', which seek to implement awareness initiatives with the various composers in the supply chain. The authors argue that an individual with a conscious mind is able, informally, to share his knowledge with his partners and to spread sustainability importance in the environment in which they operate more efficiently than through formal training. Furthermore, the speed of learning, when informally, is also higher.

Faced with internal and external pressures for GSCM adoption, organizations are increasing efforts to implement ecological practices that take into account environmental problems, natural resources depletion, environmental pollution, global warming 
and consequent decrease in biological diversity (SHAFIQUE; ASGHAR; RAHMAN, 2017; CANKAYA; SEZEN, 2019).

In this sense, GSCM practices include reactive actions until proactive conduct, such as recycling, reuse and reverse logistics (HASHEMI; KARIMI; TAVANA, 2015). Yu et al. (2014) propose that, in relation to production, companies seek sources of alternative inputs to the natural resources use, in addition to minimizing the production of hazardous materials that may contaminate soil, air, and water. In this sense, companies are increasingly investing in environmental certifications, eco innovation and ecological product design, which even includes the packaging remanufacturing taking into account the correct disposal (YU et al., 2014; SHAFIQUE; ASGHAR; RAHMAN, 2017).

However, GSCM practices also extend to the external environment, through programs aimed at raising customer awareness (whether the final consumer, the supplier, or the employee himself) (MATHIYAZHAGAN et al., 2015). The environmental practices' effectiveness depends heavily on the materials and supplies coming from suppliers and, in this sense, client companies must offer support so that their suppliers adopt ecologically correct practices and processes. Together with its final customers, the company must, in addition to meeting their needs, promote the incentive for correct disposal after using the product, that is, promote reverse logistics, in addition to encouraging, through marketing practices, the importance about consuming products managed in light of environmental issues (YU et al., 2014).

Several authors consider that the result of the implementation of the GSCM is explicit mainly in the company's economic performance. However, by adopting environmentally friendly actions, the company generates and obtains internal and external social benefits. Tseng, and Chiu (2013) argue that the efficiency and synergy between the supply chain makes environmental performance more fluid, minimizes waste and reduces costs. More specifically in relation to costs, Yu et al. (2014) admit that the greater the after-sales support to customers, the more the company gains return on products for recycling and consequently manages to reduce expenses with the disposal of materials. In contrast, Genovese et al. (2017) point out that green management allows the company to create competitive advantage, operate in new markets, in addition to improving production efficiency, in terms of quality, productivity, delivery, and flexibility.
In short, investment in GSCM practices affects environmental and business performance by being oriented towards protecting the environment by reducing waste. Such a reduction or "redesign" does not imply in minimizing the functionality or cost of the product, but in its recovery and reuse, a fact that directly impacts the cost of remanufacturing (SHAFIQUE; ASGHAR; RAHMAN, 2017).

Similar to the extension of GSCM practices to final customers and suppliers, the collaboration concept in this management model aims at synergy between the various components of the chain, so that environmental and consumption expectations are satisfactorily met (CARBALLO-PENELA et al., 2018; CANKAYA; SEZEN, 2019). Especially in the phase of converting conventional practices to green management practices, some members of the chain are unable to manage their charges independently (CARBALLO-PENELA et al., 2018). Thus, a highly integrated GSCM allows a flow of materials and information that mainly result in competitive advantage and business success (TSENG; CHIU, 2013; YU et al., 2014).

Finally, this study also intended to indicate future research directions on GSCM. In general, it is possible to classify the resulting analyses into four topics: I) the use of methods, such as DEMATEL or interpretive structural modeling, for analysis and green suppliers' selection; II) to extend green and sustainable practices in production and quality management tools, such as just in time, lean manufacturing and total quality management and control; III) to develop environmental performance indicators for sectors other than manufacturing; and IV) understand the influence of the cultural context in the GSCM practices implementation.

In the same way, e-commerce is growing (SALLNÄS; BJÖRKLUND, 2020) and, as a consequence, future research should look at how electronic retailers can approach distributors and buyers and how this relationship can influence the adoption of GCSV.

\section{FINAL REMARKS}

This study provides a bibliometric overview about GSCM and environmental sustainability. The quantitative-descriptive objective included the historical evolution of publications analysis, where it is possible to identify from 2007 , that in the studies that met the search criteria, there is a great rise in the subject, mainly from 2018 until 2020 . The authorship analysis showed that the North-American Joseph 
Sarkis is the author with the most publications on GSCM. In relation to countries, the results show that the United States and China are those with the largest affiliated research institutions. The Journal of Cleaner Production is the one that indexes the largest number of papers on GSCM, due to its high-impact factor. Finally, the keywords' analysis that characterize the theme showed that the term "green" still appears discreetly in publications.

The use of two databases showed that both complement each other, despite having some duplicates. It was also possible to identify, for example, that most of the documents are not categorized in Administration and Management, but in the Environmental Sciences (Scopus) and Environmental Engineering (Web of Science). Therefore, discussions about GSCM also take on a philosophical perspective in the Environmental Sciences area, which includes environmental contemplation versus capitalism and productivity. When belonging to the category of Environmental Engineering, the main discussion of the works concerns the eco-design and eco-innovation adoption.

In addition, the wide choice of two keywords for capturing documents proved to be efficient when rescuing the most diverse themes that relate GSCM and environmental sustainability. Thus, the complementary qualitative analysis identified that the relationship between supply chain and sustainability occurs, mainly, through the ecological practices' adoption, specifically, with investments on reverse logistics. The main sector studied is the automotive sector, notably in Asian countries. Studies in general are limited to discussing mainly the barriers that prevent adoption of green management practices, but the possibility of literary growth regarding the making of models for selecting green suppliers from far-reaching methodologies.

The combination of a mixed methodology proposed in this study allowed the graphical and tabulated results to be confirmed by the quantitative exploratory analysis, whose future studies may establish connections between several variables. In this way, this study contributes, theoretically, to the field of GSCM as it updates the state-of-the-art of the theme, in the last twenty years, and complements other bibliometric reviews. Secondly, this study investigated not only quantitatively the themes that link GSCM and environmental sustainability in scientific articles, but qualitatively by proposing a synthesis of the main issues discussed in each continent. Thirdly, suggestions for future research were made.
For the GSCM field of knowledge in general, it could be concluded that GSCM practices adoption is mainly driven by consumers, which has acquired a greater awareness of environmental problems. However, the main difficulty in spreading GSCM is to harmonize all members of the chain so that the entire production process is sustainable. This fact is even identified in the research problems of the selected studies, that is, due to the immaturity of the theme, there is no harmony between the studies and, consequently, more efficient practices are still unknown, and the charges differ according to the sector, indicating that the theme is still under development.

The study presented here has some limitations that deserve consideration. First, this research provides generalized information about a theme systematized in filters adopted subjectively by the authors. Secondly, only two databases were used and, therefore, researches published in journals not indexed in Scopus and Web of Science were not considered. Thirdly, articles were analyzed in the English language only, ignoring works published in other languages. The time frame also influenced the analysis, and, it must be considered, that such results are dynamic and change over time. Likewise, by excluding other document types, like book chapters and conference proceedings, there is a limitation in the theme interpretation and conclusions. Finally, other perspectives could have been considered, although in general, results with wide divergences are not expected.

Due to all limitations listed, it is suggested that future bibliometric research should consider the intersections between the field of green supply chain management with other areas considering different types of documents, languages, and periods. This article emphasized the study of the environmental dimension influence in the green supply chain management. Therefore, the social and economic dimensions that are part of the sustainability 'tripod' have not been addressed. Thus, future research should seek to understand how complex sustainable management is, considering the triple bottom line, in sustainable supply chains.

\section{REFERENCES}

ALTAF, Bothinah; ALI, Sadia Samar; WEBER, GerhardWilhelm. Modeling the relationship between organizational performance and green supply chain practices using canonical correlation analysis. Wireless Networks, v. 26, n. 8 p. 5835-5853, 30 mar. 2020. http://dx.doi.org/10.1007/s11276-020-02313-3. 
AMIRBAGHERI, Keivan; Nõ̃EZ-CARBALLOSA, Ana; GUITART-TARRÉS, Laura; MERIGÓ, José M. Research on green supply chain: a bibliometric analysis. Clean Technologies And Environmental Policy, v. 21, n. 1, p.

AGARWAL, Atul; GIRAUD-CARRIER, François C.; LI, Yuan. A mediation model of green supply chain management adoption: the role of internal impetus. International Journal Of Production Economics, v. 205, p. 342-358, nov. 2018. http://dx.doi.org/10.1016/j.ijpe.2018.09.011.

CANKAYA, Sibel Yildiz; SEZEN, Bulent. Effects of green supply chain management practices on sustainability performance. Journal Of Manufacturing Technology Management, v. 30, n. 1, p. 98-121, 21 jan. 2019. http://dx.doi.org/10.1108/jmtm-03-2018-0099.

CARBALLO-PENELA, Adolfo; MATEO-MANTECÓN, Ingrid; ALVAREZ, Sergio; CASTROMÁN-DIZ, Juan Luis. The Role of green collaborative strategies in improving environmental sustainability in supply chains: insights from a case study. Business Strategy And The Environment, v. 27, n. 6, p. 728-741, 12 dez. 2017. http://dx.doi.org/10.1002/bse.2027.

CARVALHO, Lucas Silvestre de; STEFANELLI, Nelson Oliveira; VIANA, Lilian Carolina; VASCONCELOS, Diogo de Siqueira Camargo; OLIVEIRA, Bruno Garcia. Green supply chain management and innovation: a modern review. Management Of Environmental Quality: An International Journal, v. 31, n. 2, p. 470-482, 6 mar. 2020. http://dx.doi.org/10.1108/meq-12-2019-0283.

FAHIMNIA, Behnam; SARKIS, Joseph; DAVARZANI, Hoda. Green supply chain management: a review and bibliometric analysis. International Journal Of Production Economics, v. 162, p. 101-114, abr. 2015. http://dx.doi.org/10.1016/.i.jpe.2015.01.003.

GENOVESE, Andrea; ACQUAYE, Adolf A.; FIGUEROA, Alejandro; $\mathrm{KOH}$, S.C. Lenny. Sustainable supply chain management and the transition towards a circular economy: evidence and some applications. Omega, v. 66, p. 344-357, jan. 2017. http://dx.doi.org/10.1016/j.omega.2015.05.015.

GIANNETTI, B.F.; AGOSTINHO, F.; ERAS, J.J. Cabello; YANG, Zhifeng; ALMEIDA, C.M.V.B.. Cleaner production for achieving the sustainable development goals. Journal Of Cleaner Production, v. 271, p. 122127, out. 2020.

GONG, Ruifeng; XUE, Jian; ZHAO, Laijun; ZOLOTOVA, Oleksandra; JI, Xiaoqing; XU, Yan. A Bibliometric Analysis of Green Supply Chain Management Based on the Web of Science (WOS) Platform. Sustainability, v. 11, n. 12, p. 3459, 24 jun. 2019. http://dx.doi.org/10.3390/su11123459.
GOVINDAN, Kannan; RAJEEV, A.; PADHI, Sidhartha S.; PATI, Rupesh K.. Supply chain sustainability and performance of firms: a meta-analysis of the literature. Transportation Research Part e: Logistics and Transportation Review, v. 137, p. 101923, maio 2020. http://dx.doi.org/10.1016/j.tre.2020.101923.

HASHEMI, Seyed Hamid; KARIMI, Amir; TAVANA, Madjid. An integrated green supplier selection approach with analytic network process and improved Grey relational analysis. International Journal Of Production Economics, v. 159, p. 178-191, jan. 2015. http://dx.doi.org/10.1016/j.ijpe.2014.09.027.

JAYARATHNA, B.C.P.; WICKRAMASINGHE, C.N.. Determinants of green supply chain practices of manufacturing companies in Sri Lanka. International Journal Of Productivity And Quality Management, v. 28, n. 1, p. 103, 2019. http://dx.doi.org/10.1504/ijpqm.2019.102426.

JAZAIRY, Amer. Aligning the purchase of green logistics practices between shippers and logistics service providers. Transportation Research Part D: Transport and Environment, v. 82, p. 102305, maio 2020. http://dx.doi.org/10.1016/j.trd.2020.102305.

KHAN, Syed Abdul Rehman; SHARIF, Arshian; GOLPÎRA, Hêriş; KUMAR, Anil. A green ideology in Asian emerging economies: from environmental policy and sustainable development. Sustainable Development, v. 27, n. 6 , p. 1063-1075, 18 jun. 2019. http://dx.doi.org/10.1002/sd.1958.

MANI, Venkatesh; JABBOUR, Charbel Jose Chiappetta; MANI, Kavitha T.N. Supply chain social sustainability in small and medium manufacturing enterprises and firms' performance: empirical evidence from an emerging asian economy. International Journal Of Production Economics, v. 227, p. 107656, set. 2020. http://dx.doi.org/10.1016/j.ijpe.2020.107656.

MATHIYAZHAGAN, K.; DIABAT, Ali; AL-REFAIE, Abbas; $X U$, Lei. Application of analytical hierarchy process to evaluate pressures to implement green supply chain management. Journal Of Cleaner Production, v. 107, p. 229236, nov. 2015. http://dx.doi.org/10.1016/j.jclepro.2015.04.110.

MODAK, Nikunja Mohan; SINHA, Sudipta; RAJ, Alok; PANDA, Shibaji; MERIGÓ, José M.; JABBOUR, Ana Beatriz Lopes de Sousa. Corporate social responsibility and supply chain management: framing and pushing forward the debate. Journal Of Cleaner Production, v. 273, p. 122981, nov. 2020. http://dx.doi.org/10.1016/j.jclepro.2020.122981. 
OLIVEIRA, Ualison Rébula de; ESPINDOLA, Luciano Souza; SILVA, Isabele Rocha da; SILVA, Iaslin Nostório da; ROCHA, Henrique Martins. A systematic literature review on green supply chain management: research implications and future perspectives. Journal Of Cleaner Production, v. 187, p. 537-561, jun. 2018. http://dx.doi.org/10.1016/j.jclepro.2018.03.083.

PHAWITPIRIYAKLITI, Chaithanaskorn; KEAWKUNTI, Boonthai; SAISAMA, Chompoo; SANGMA, Watcharin. TOWARDS ENVIRONMENTAL SUSTAINABILITY: a case study of green supply chain management practice. Journal Of Security And Sustainability Issues, v. 9, n. 3, p. 747-763, 25 mar. 2020. http://dx.doi.org/10.9770/jssi.2020.9.3(2).

SAHU, Atul Kumar; NARANG, Harendra Kumar; RAJPUT, Mridul Singh; SAHU, Nitin Kumar; SAHU, Anoop Kumar. Performance modeling and benchmarking of green supply chain management. Benchmarking: An International Journal, v. 25, n. 7, p. 2248-2271, 1 out. 2018. http://dx.doi.org/10.1108/bij-02-2017-0032.

SALLNÄS, Uni; BJÖRKLUND, Maria. Consumers' influence on the greening of distribution - exploring the communication between logistics service providers, e-tailers and consumers. International Journal Of Retail \& Distribution Management, v. 48, n. 11, p. 1177-1193, 25 jun. 2020. http://dx.doi.org/10.1108/ijrdm-07-2019-0213.

SANGODE, Pallawi; METRE, Sujit. Green Supply Chain Practices for Environmental Sustainability A Proposed Framework for Manufacturing Firms. International Journal Of Mechanical And Production Engineering Research And Development, v. 9, n. 2, p. 287-298, 2019. http://dx.doi.org/10.24247/ijmperdapr201928.

SARKIS, Joseph; KOUHIZADEH, Mahtab; ZHU, Qingyun Serena. Digitalization and the greening of supply chains. Industrial Management \& Data Systems, v. 121, n. 1 , p. $65-85,20$ out. 2020 . http://dx.doi.org/10.1108/imds08-2020-0450.

SHAFIQUE, Muhammad; ASGHAR, Muhammad; RAHMAN, Haji. The Impact of Green Supply Chain Management Practices on Performance: moderating role of institutional pressure with mediating effect of green innovation. Business, Management And Education, v. 15, n. 1, p. 91-108, 29 jun. 2017. http://dx.doi.org/10.3846/bme.2017.354.
SHAH, Tejas R. Green supply chain management: learning from indian chemical sector. International Journal Of Business Performance And Supply Chain Modelling, v. 11, n. 1 , p. 1, 2020. http://dx.doi.org/10.1504/ijbpscm.2020.108885.

SHEN, Lixin; OLFAT, Laya; GOVINDAN, Kannan; KHODAVERDI, Roohollah; DIABAT, Ali. A fuzzy multi criteria approach for evaluating green supplier's performance in green supply chain with linguistic preferences. Resources, Conservation And Recycling, v. 74, p. 170-179, maio 2013. http://dx.doi.org/10.1016/j.resconrec.2012.09.006.

SILVESTRE, Bruno S.; SILVA, Minelle E.; CORMACK, Allan; THOME, Antônio Márcio Tavares. Supply chain sustainability trajectories: learning through sustainability initiatives. International Journal Of Operations \& Production Management, v. 40, n. 9, p. 1301-1337, 18 jun. 2020. http://dx.doi.org/10.1108/ijopm-01-2020-0043.

TSENG, Ming-Lang; ISLAM, Md Shamimul; KARIA, Noorliza; FAUZI, Firdaus Ahmad; AFRIN, Samina. A literature review on green supply chain management: trends and future challenges. Resources, Conservation And Recycling, v. 141, p. 145-162, fev. 2019. http://dx.doi.org/10.1016/j.resconrec.2018.10.009.

TSENG, Ming-Lang; CHIU, Anthony S.F.. Evaluating firm's green supply chain management in linguistic preferences. Journal Of Cleaner Production, v. 40, p. 22-31, fev. 2013. http://dx.doi.org/10.1016/j.jclepro.2010.08.007.

VAN ECK, Nees Jan; WALTMAN, Ludo. Software survey: vosviewer, a computer program for bibliometric mapping. Scientometrics, v. 84 , n. 2, p. 523-538, $31 \mathrm{dez}$. 2009. http://dx.doi.org/10.1007/s11192-009-0146-3. ZHOU, Xinyu; LI, Tuochen; MA, Xiaoqi. A bibliometric analysis of comparative research on the evolution of international and Chinese green supply chain research hotspots and frontiers. Environmental Science And Pollution Research, v. 28, n. 6, p. 6302-6323, 2 jan. 2021. http://dx.doi.org/10.1007/s11356-020-11947-x.

YU, Wantao; CHAVEZ, Roberto; FENG, Mengying; WIENGARTEN, Frank. Integrated green supply chain management and operational performance. Supply Chain Management: An International Journal, v. 19, n. 5/6, p. 683-696, 2 set. 2014. http://dx.doi.org/10.1108/scm-07-2013-0225. 


\section{APPENDIX A}

\begin{tabular}{|c|c|c|c|c|}
\hline Title & Scopus & Web of Science & Year & Authors \\
\hline $\begin{array}{c}\text { Green supply chain management: Pressures, prac- } \\
\text { tices and performance within the Chinese automobile } \\
\text { industry }\end{array}$ & 655 & 537 & 2007 & Zhu et al. \\
\hline $\begin{array}{l}\text { Environmental management and manufacturing per- } \\
\text { formance: The role of collaboration in the supply chain }\end{array}$ & - & 764 & 2008 & Vachon Klassen \\
\hline $\begin{array}{l}\text { Linking supply chain strength to sustainable develop- } \\
\text { ment: A country-level analysis }\end{array}$ & 200 & 150 & 2008 & Vachon; Mao \\
\hline $\begin{array}{l}\text { Balancing priorities: Decision-making in sustainable } \\
\text { supply chain management }\end{array}$ & 436 & 373 & 2011 & Wu; Pagell \\
\hline $\begin{array}{c}\text { Green supply chain initiatives among certified compa- } \\
\text { nies in Malaysia and environmental sustainability: In- } \\
\text { vestigating the outcomes }\end{array}$ & 388 & 269 & 2011 & Eltayeb et al. \\
\hline $\begin{array}{l}\text { Do green supply chain management initiatives impact } \\
\text { stock prices of firms? }\end{array}$ & 76 & - & 2012 & Bose; Pal \\
\hline $\begin{array}{l}\text { Environmental sustainability: A value cycle research } \\
\text { agenda }\end{array}$ & 35 & 33 & 2012 & Barber et al. \\
\hline $\begin{array}{c}\text { Green supply chain management practices: Impact on } \\
\text { performance }\end{array}$ & 601 & 457 & 2012 & Green Jr. et al. \\
\hline $\begin{array}{c}\text { A fuzzy multi criteria approach for evaluating green } \\
\text { supplier's performance in green supply chain with lin- } \\
\text { guistic preferences }\end{array}$ & 267 & 216 & 2013 & Shen et al. \\
\hline $\begin{array}{l}\text { A meta-analysis of environmentally sustainable supply } \\
\text { chain management practices and firm performance }\end{array}$ & 340 & 287 & 2013 & Golicic; Smith \\
\hline $\begin{array}{c}\text { An exploration of green supply chain practices and } \\
\text { performances in an automotive industry }\end{array}$ & 94 & 74 & 2013 & Diabat et al. \\
\hline $\begin{array}{c}\text { Designing an environmental sustainable supply chain } \\
\text { through ISO } 14001 \text { standard }\end{array}$ & 50 & - & 2013 & Chiarini \\
\hline $\begin{array}{c}\text { Evaluating firm's green supply chain management in } \\
\text { linguistic preferences }\end{array}$ & & 188 & 2013 & Tseng; Chiu \\
\hline $\begin{array}{l}\text { Adoption of green supply chain management practices } \\
\text { and their impact on performance: An exploratory study } \\
\text { of Indian manufacturing firms }\end{array}$ & 186 & 155 & 2014 & Mitra; Datta \\
\hline $\begin{array}{l}\text { Multiple comparative studies of green supply chain } \\
\text { management: Pressures analysis }\end{array}$ & 81 & 70 & 2013 & Xu et al. \\
\hline $\begin{array}{l}\text { Empirical analysis of green supply chain management } \\
\text { practices in Indian automobile industry }\end{array}$ & 20 & - & 2014 & Luthra et al. \\
\hline $\begin{array}{c}\text { Integrated green supply chain management and oper- } \\
\text { ational performance }\end{array}$ & 103 & 83 & 2014 & Yu et al. \\
\hline $\begin{array}{c}\text { An integrated green supplier selection approach with } \\
\text { analytic network process and improved grey relational } \\
\text { analysis }\end{array}$ & 261 & 220 & 2015 & $\begin{array}{l}\text { Hashemi; Karimi; Ta- } \\
\text { vana }\end{array}$ \\
\hline $\begin{array}{l}\text { Application of analytical hierarchy process to evaluate } \\
\text { pressures to implement green supply chain manage- } \\
\text { ment }\end{array}$ & 66 & 56 & 2015 & Mathiyazhagan et al. \\
\hline $\begin{array}{l}\text { Green supply chains: A perspective from an emerging } \\
\text { economy }\end{array}$ & 107 & 88 & 2015 & Jayaram; Avittathur \\
\hline $\begin{array}{l}\text { Green supply chain management and firms' perfor- } \\
\text { mance: Understanding potential relationships and the } \\
\text { role of green sourcing and some other green practices }\end{array}$ & 71 & 57 & 2015 & Jabbour et al. \\
\hline $\begin{array}{c}\text { Industrial ecology, industrial symbiosis and supply } \\
\text { chain environmental sustainability: A case study of a } \\
\text { large UK distributor }\end{array}$ & 61 & 49 & 2015 & Leigh; Li \\
\hline
\end{tabular}




\begin{tabular}{|c|c|c|c|c|}
\hline Title & Scopus & Web of Science & Year & Authors \\
\hline $\begin{array}{l}\text { Mitigating external barriers to implementing green sup- } \\
\text { ply chain management: A grounded theory investiga- } \\
\text { tion of green-tech companies' rare earth metals supply } \\
\text { chains }\end{array}$ & 70 & 58 & 2015 & Rauer; Kaufmann \\
\hline $\begin{array}{c}\text { Stakeholder pressure in sustainable supply chain } \\
\text { management A systematic review }\end{array}$ & 137 & 122 & 2015 & Meixell; Luoma \\
\hline $\begin{array}{l}\text { Sustainable supply chain management and the transi- } \\
\text { tion towards a circular economy: Evidence and some } \\
\text { applications }\end{array}$ & 321 & 281 & 2015 & Genovese et al. \\
\hline $\begin{array}{c}\text { Assessing the impact of green supply chain practices } \\
\text { on firm performance in the Korean manufacturing in- } \\
\text { dustry }\end{array}$ & 24 & 17 & 2017 & Choi et al. \\
\hline $\begin{array}{l}\text { Suppliers' green performance evaluation using fuzzy } \\
\text { extended ELECTRE approach }\end{array}$ & 27 & 26 & 2017 & Kumar et al. \\
\hline $\begin{array}{l}\text { Supply chain perspective on competitive strategies } \\
\text { and green supply chain management strategies }\end{array}$ & 45 & 39 & 2017 & Laari et al. \\
\hline $\begin{array}{l}\text { The impact of green supply chain management prac- } \\
\text { tices on performance: Moderating role of institutional } \\
\text { pressure with mediating effect of green innovation }\end{array}$ & - & 9 & 2017 & Shafique et al. \\
\hline $\begin{array}{l}\text { Performance modeling and benchmarking of green } \\
\text { supply chain management: An integrated fuzzy ap- } \\
\text { proach }\end{array}$ & 9 & 5 & 2017 & Sahu et al. \\
\hline $\begin{array}{l}\text { A mediation model of green supply chain management } \\
\text { adoption: The role of internal impetus }\end{array}$ & 9 & 9 & 2018 & $\begin{array}{l}\text { Agarwal; Giraud-Car- } \\
\text { rier; Li }\end{array}$ \\
\hline $\begin{array}{l}\text { A novel integrated approach for green supplier selec- } \\
\text { tion with interval-valued intuitionistic uncertain linguis- } \\
\text { tic information: A case study in the agri-food industry }\end{array}$ & 20 & 12 & 2018 & Shi et al. \\
\hline $\begin{array}{l}\text { Effects of green supply chain management practices } \\
\text { on sustainability performance }\end{array}$ & - & 2 & 2018 & Cankaya; Sezen \\
\hline $\begin{array}{l}\text { Green supply chain management, economic growth } \\
\text { and environment: A GMM based evidence }\end{array}$ & 75 & 64 & 2018 & Khan et al. \\
\hline $\begin{array}{c}\text { Performance of green supply chain management: A } \\
\text { systematic review and meta analysis }\end{array}$ & 51 & 37 & 2018 & Fang; Zhang \\
\hline $\begin{array}{l}\text { The relationship between environment and logistics } \\
\text { performance: Evidence from Asian countries }\end{array}$ & 47 & 38 & 2018 & Liu et al. \\
\hline $\begin{array}{l}\text { The role of green collaborative strategies in improving } \\
\text { environmental sustainability in supply chains: Insights } \\
\text { from a case study }\end{array}$ & 13 & 12 & 2018 & $\begin{array}{l}\text { Carballo-Penela et } \\
\text { al. }\end{array}$ \\
\hline $\begin{array}{l}\text { A green ideology in Asian emerging economies: From } \\
\text { environmental policy and sustainable development }\end{array}$ & 55 & 48 & 2019 & Khan et al. \\
\hline $\begin{array}{l}\text { Analysing the institutional pressures on shippers and } \\
\text { logistics service providers to implement green supply } \\
\text { chain management practices }\end{array}$ & 0 & - & 2019 & $\begin{array}{l}\text { Jazairy; von Haart- } \\
\text { man }\end{array}$ \\
\hline $\begin{array}{c}\text { Determinants of green supply chain practices of man- } \\
\text { ufacturing companies in Sri Lanka }\end{array}$ & 0 & - & 2019 & $\begin{array}{l}\text { Jayarathna; Wickra- } \\
\text { masingh }\end{array}$ \\
\hline $\begin{array}{c}\text { Green supply chain management in construction: A } \\
\text { systematic literature review and future research } \\
\text { agenda }\end{array}$ & 0 & 0 & 2019 & Badi; Murtagh \\
\hline $\begin{array}{l}\text { Green supply chain practices for environmental sus- } \\
\text { tainability: A proposed framework for manufacturing } \\
\text { firms }\end{array}$ & 0 & - & 2019 & Sangode; Metre \\
\hline $\begin{array}{l}\text { Investigating green supply chain management prac- } \\
\text { tices and performance: The moderating roles of supply } \\
\text { chain ecocentricity and traceability }\end{array}$ & 0 & 0 & 2019 & Cousins et al. \\
\hline
\end{tabular}




\begin{tabular}{|c|c|c|c|c|}
\hline Title & Scopus & Web of Science & Year & Authors \\
\hline $\begin{array}{l}\text { To be or not to be green? Strategic investment for } \\
\text { green product development in a supply chain }\end{array}$ & 23 & - & 2019 & Dong et al. \\
\hline $\begin{array}{l}\text { Aligning the purchase of green logistics practices be- } \\
\text { tween shippers and logistics service providers }\end{array}$ & 2 & 1 & 2020 & Jazairy \\
\hline $\begin{array}{l}\text { Consumers' influence on the greening of distribution: } \\
\text { Exploring the communication between logistics service } \\
\text { providers, e-tailers and consumers }\end{array}$ & 1 & 0 & 2020 & Sallnäs; Björklund \\
\hline Digitalization and the greening of supply chains & 0 & 0 & 2020 & Sarkis et al. \\
\hline $\begin{array}{l}\text { Green supply chain management: Learning from In- } \\
\text { dian chemical sector }\end{array}$ & 0 & - & 2020 & Shah \\
\hline $\begin{array}{c}\text { Green supply chain performance and environmental } \\
\text { sustainability: A panel study }\end{array}$ & 6 & 5 & 2020 & Khan et al. \\
\hline $\begin{array}{c}\text { Modeling the relationship between organizational per- } \\
\text { formance and green supply chain practices using ca- } \\
\text { nonical correlation analysis }\end{array}$ & 2 & 2 & 2020 & Altaf; Ali; Weber \\
\hline $\begin{array}{c}\text { Paradoxes in supplier's uptake of GSCM practices: Is- } \\
\text { titutional drivers and buyer dependency }\end{array}$ & - & 1 & 2020 & Fayezi et al. \\
\hline $\begin{array}{l}\text { Role of green supply chain management strategies in } \\
\text { sustainability: Evidence form manufacturing industry of } \\
\text { Thailand }\end{array}$ & 0 & - & 2020 & Mekhum \\
\hline $\begin{array}{c}\text { Towards environmental sustainability: A case study of } \\
\text { green supply chain management practice }\end{array}$ & 1 & - & 2020 & Phawitpiriyakliti et al. \\
\hline
\end{tabular}

